\title{
The Human Rights State and Freedom of Religion in the Southeastern Europe: The Case of Bosnia-Herzegovina
}

By Gorana Ognjenović and Jasna Jozelić ${ }^{1}$

\author{
Norwegian Center for Human Rights, University in Oslo
}

\begin{abstract}
While in today's academic research on HR the focus primarily lies on the promotion of freedom of religion in a positive sense, analysis of the misuse of the same freedom of religion remains a black hole, in which researchers seem hesitant to explore. The politicization of religion for the purpose of causing ethnic conflict on the territory of Bosnia and Herzegovina during the 1990s and until today represents an example from which lessons can be drawn for the current situation in Ukraine, or the ongoing crisis in Syria. The Balkanization of Europe has only continued to grow into a global crisis. The need for finding ways of neutralizing such attempts at cynical misuse, which was originally intended as a means to bring justice for all in a way provided by Benjamin Greg's model of HRS, seems only to grow as time goes by and as the new ways of misusing such rights seem to multiply endlessly. In the case of Bosnia and Herzegovina, education would appear to be the most essential channel for spreading the acceptance for such an approach, so that at least new generations will have a chance of surviving together the complexity of everyday life in a multi-ethnic community that is torn apart by a bloody conflict and a dysfunctional peace agreement such as Dayton agreement.
\end{abstract}

Key words: politicization of religion; freedom of religion; constitution; Bosnia and Herzegovina; Human Rights State; Dayton agreement; education; multi-ethnicity, common ethos, national identity.

\section{Introduction}

During the 1990s wars in Former Yugoslavia academics such as Anthony Giddens ${ }^{1}$ attempted to explain what had gone wrong that caused the unimaginable bloodshed on European ground. These attempts only demonstrated that western academia ${ }^{2}$ like religious fundamentalism ${ }^{3}$ was unable to distinguish between the right to practice religion and the politicization of religion for achieving a political goal, ${ }^{4}$ as religious nationalism ${ }^{5}$ was in this case. In his explanation, Giddens accused the entire population of South-eastern Europe for religious fundamentalists. ${ }^{6}$

Religion has always been a historical force in Balkan societies. During the 90s especially, it has defined social identities and has been used as a basis for national myths. ${ }^{7}$ In the case of the wars in Former Yugoslavia, it is more than clear, that religion was heavily instrumentalized for the purpose of motivating religious nationalism, for the purpose of genocide (genocidal rape included ${ }^{8}$ ) and other war crimes during the 1990s. ${ }^{9}$ However, there is a vast difference between practicing religion and using religion as a political tool for religious nationalism which contributed to taking Tito's Yugoslavia apart. ${ }^{10}$

\footnotetext{
${ }^{1}$ Corresponding authors: ognjenagora@gmail.com, jasna.jozelic@nchr.uio.no.
} 
What has changed since the 90s wars in Former Yugoslavia, through the transition period that followed, until today, is that the politicization actually never stopped but that is only used for achieving different political goals. ${ }^{11}$ On the one hand, practicing freedom of religious belief plays a new role in society as an indicator of as the degree societies have been democratized. ${ }^{12}$ On the other hand, once the common culture and heritage identified religion as a part of tradition, religion became a major element on the political scene. Previously, nationalists instrumentalized religion for factual ontologization of the existing social, political and cultural differences ${ }^{13}$ that legitimized political violence and ethnic cleansing practiced by all aggressors. ${ }^{14}$ Today religion is again politicized in the same manner but this time it targets also other and different groups within the borders of the same nation state, as well as promoting territorial claims to Bosnia and Herzegovina's territory by neighbouring nation states. Bosnia and Herzegovina had been through history politically sabotaged and undermined by both Croatia and Serbia. ${ }^{15}$ What is new in about the methodology of conducting politicization of religion is far more subtle, and concentrated on causing totalitarian effects through democratic means, such as a referendum ${ }^{16}$, which makes pinpointing their ways of achieving their extreme political goals far more difficult.

During the conflict, Bosnia and Herzegovina had been thoroughly artificially homogenized through genocide and ethnic cleansing. As a result of signing the Dayton peace agreement in 1995, the country has been also administratively divided along the new artificial main ethnic/religious lines (Bosnian Catholics \& Bosnian Muslims versus Bosnian Orthodox) into Federation versus RS. ${ }^{17}$ In Bosnia and Herzegovina still today in the absence of a real constitution, due to political disagreements, the Dayton peace agreement functions as a constitution even though it was never intended to do so.

This is why in our contribution we shall focus on an analysis of the relationship between the right to freedom of religion, state secularism and politicization of religion in the light of the Benjamin Gregg's Human Rights State concept. We understand Gregg's Human Rights State as a concept/model for a possible transformation/developing the model of nation states further into a 'state for all', where all people, regardless of citizenship status or territorial location, would everywhere be recognized as bearers of human rights. Further we understand Gregg's approach as departing from the usual 'top to bottom' understanding of human rights being only a product of and enforced by an international legislation and going for a 'bottom up' approach where human rights are seen as a product of and recognized and enforced by local political communities in all of their particularity.

Concerning the method of our analysis in this particular contribution it is primarily based on our own historical research because analysis of this particular theme, politicization of religion, concerning Bosnia and Herzegovina or any other country as a nation state, does not previously exist. Our analysis includes also critical reading of legal documents in relation to historicity of freedom of religion on the territory of Former Yugoslavia. We claim that our path breaking analysis shows a way for studies of the same phenomenon in other countries around the globe.

OUR THESIS: We shall normatively argue, based on our historical study ${ }^{18}$ that a constructivist approach such as the HR State has an applicable solution to offer when it comes to the peoples of Bosnia and Herzegovina, in their search for a common ethos as a source of lasting peace. The HR State would among other rights treat freedom of religion as one of 
many rights that can be included in the constitution, only after the very basic rights ${ }^{19}$ for all have been included and respected as such, irrespective of their religious or ethnic background.

The essential reason as to why Benjamin's HRS is relevant for the situation in Bosnia and Herzegovina, today, is the fact that it treats freedom of religion as an optional human right and not an essential human right necessary for existence of a HRS. By doing so, Benjamin's model opens up for the possibility of building a common ethos across civil society in Bosnia and Herzegovina irrespective of religious or ethnic affiliation to a certain group.

The search for a common ethos is the only way to challenge the current artificially created borderlines of homogenized Bosnia and Herzegovina, as it is today.

The concept of a Humans Rights State offers an alternative perspective in a way that even though it suggests a possibility of having a common system of values (including secular and religious) it also offers a possible model for the autonomous practice of the same rights individually, based on Greggs concept of autonomy. ${ }^{20}$

We shall argue that if Bosnia and Herzegovina today, split along the ethnic borderlines, would follow Greg's suggestion for moving from the standard interpretation of HR (Human rights are moral principles and norms, which describe certain standards of human behavior, and are regularly protected as legal rights in municipal and international law. ${ }^{21}$ ) towards Gregg's alternative interpretation of Human rights than the outcome of the situation would be to the advantage of all its citizens.

In order to understand the freedom of religion in Bosnia and Herzegovina today, one must first take a step back and look at the position of freedom of religion in Former Yugoslavia, since Bosnia and Herzegovina is one of the successor states previously based on a common constitution.

There on, we shall look at the similarities between the situation in Former Yugoslavia and Successor States Transition and finally we shall look at the role of individual autonomy and education in our pursuit of the transition towards the Human Rights State.

\section{Freedom of religion in Former Yugoslavia}

The freedom of religion and conscience is not a new legal or cultural concept in the context of the Former Yugoslav successor states. The crucial idea behind Gregg's model ${ }^{22}$ anchoring the freedom of religion as a right in domestic constitutions, for the purpose of building a new nation state (Tito's Yugoslavia) tolerant of all religious and ethnic differences, has been done by Tito's government in the case of Former Yugoslavia. Prescribing religion to the private sphere in Tito's Yugoslavia was nothing but an attempt to prevent the abuse of religion for a specific political purpose: An urgent attempt to keep under control developments of ethnic and religious hate resulting from civil atrocities during World War Two. In the Constitution of Former Yugoslavia from 1946, Article 25 prescribed the states' relationship to religion:

"The state guarantees citizens their freedom of conscience and freedom of religion. The church is separate from the state; religious communities whose teachings do not work against the Constitution, are free to conduct their activities and religious rituals. Seminaries are free but under the states' surveillance. The abuse of church and religion for political purposes is forbidden, together with political organizations based on religion. The state can financially assist religious communities." 23 
The law was passed on May 25, 1945, and prohibited the provocation of national, racial, or religious hatred and conflict. It was the first attempt to address questions regarding state relationship and religion. ${ }^{24}$ This legislative model that separated religion and state, declared religion as a private matter for each individual.

In Former Yugoslavia three amendments to the constitution were made, which included a few changes regarding state (constitutional) relationship to religion, primarily considering religion as an institution and the work religious communities did within society. The constitution of socialist Yugoslavia guaranteed freedom of conscience and the practice of religion as a basic condition of freedom for all citizens in the community.

Amendments to the constitution regarding religion made in 1946, 1963, and 1974 were mainly focused on the work done by religious institutions as religious schools and the necessity of their surveillance by the state.

On the state level (i.e. that of the ruling Communist Party), ideologically religion was never seen as anything but 'an opium for the people' and religious political organizations were considered as 'enemies of the people' and dangerous for the future of the state. Even though one can say that such authoritarian methods of control of religious practice were questionable, what the state attempted by limiting religion to the private sphere was a prevention of the 'abuse of religion for political purposes such as causing ethno-nationalist conflicts', which was also considered as a capital violation against the constitution and the state.

What was the impact such legislation and implementation of law had on the citizens and their religious practice?

Trying to cause social change by introducing a new legislation alone, as in many other cases, was not the right answer. Even though the state had a monopoly regarding religious practice freedom of religion was seen by the people as one of the constitutional freedoms granted by the state, since legally practicing religion was never actually forbidden as it was in other communist countries at the time. ${ }^{25}$ The problem was that by and large society was not capable of producing conditions which would help towards developing the basic values for ensuring social justice where legislation is not the tool of state correction. The basic underlining of Gregg's model ${ }^{26}$, the question of developing a culture for the purpose of the increased understanding of what this right should mean in daily practice was raised only indirectly by developing the new Yugoslav nation. All those who were ready to identify with it since it was going to be a hybrid state, would be beyond the republics in its federation, which were based on nation states models. ${ }^{27}$ In this context, being Yugoslav meant also not practicing religion since it would mean siding with the modern state instead of choosing one's own tradition. ${ }^{28}$ The problem was that at the same time religion was seen by those, who did not feel 'Yugoslav' as a tool of manipulation that resulted frequently in an anti-Yugoslav attitude. At the same time, this legislative attempt to set up some framework of prevention against increasing ethnic conflicts within the state was seen by many in and outside of the country as one of many measures for the quick modernization of a country that prior to World War Two was a feudal province geo-strategically well-situated and therefore 'up for grabs' by its neighbours. ${ }^{29}$

\section{The enforced choice}

Considering the freedom of religion, the problem was that the grass roots in Former Yugoslavia in general interpreted the situation as one between the state and religion, as if they 
were 'forced' by the modern state (represented by the Communist Party) to make a choice concerning their chosen participation on one side or the other (Communist Party or local tradition) which had a direct impact on their daily life. Membership in the Communist Party was seen as a form of loyalty to the new State (SFRJ) while loyalty to one's congregation was looked upon as loyalty towards tradition. The 'enforced choice' by the modern state meant in daily practice choosing between either seeking career in the public sector (communist party membership obligatory and thus practicing of religion unacceptable) or seeking career in the private sector (where individual could follow her religious convictions without any political repercussions). In other words, the individual's right to choose has been sacrificed in the name of the state and 'solidarity' with the community, so that the state and local communities in this world view actually operated as antonyms. The state had built a mechanism of ideological dogmas for the purpose of 'forced modernization' of society where the individuals turned to the state and not to religion in an attempt to find meaning in life or a means of survival. By reconstructing the religious belief in this way as an enemy of the state, religion as an institution became in a common social memory a part of tradition rather than a practice of religious belief. The society was secularized and the majority of the population saw their religious identity and affiliation as a part of tradition - where cultural and religious symbolism were heavily intertwined. ${ }^{30}$ The individual's sense of being religious was also limited to following cultural tradition rather than as an expression of their individual religiousness. Practicing religion was, among all religious communities, also considered more as a form of cultural rite than religiousness. In this way the number of truly religious individuals was not ever even close to the great number of individuals who had followed religious rites as a form of following one's tradition, even though within a single religion (especially on the Christian side) there were, still are and always will be very many different traditions and cultures across the Yugoslav Successor states. Nevertheless, the constitution in socialist Yugoslavia gave a false feeling that individuals had a right to choose if not a right to practice religion. The problem was that once the freedom of religion was considered by the grass roots as a part of the private sphere it was difficult to regulate it any further by state control.

At the same time many would claim that to have that 'possibility of choice' written in the constitution was a guarantee, not just for domestic purposes but a form of guarantee for foreign purposes, especially when it came to foreign investors who presupposed or demanded such freedom in the countries in which they wished to invest in. Western countries seemed to be satisfied with religious right as an indicator of the socialist era aiming at the democratic transition which we know now never came in that sense.

\section{Emperor's new clothes: Society in Transition and "freedom of religion"}

\section{Getting lost in translation}

During the last couple of decades, as a part of the transitional change after years of conflict, international human rights legislation has had a growing impact on Yugoslav successor states' building of their domestic legislation. Demands on implementing human rights in domestic legislation from the international community as a part of the democratization process challenged the State's institutions and their capability to meet those obligations and secure the implementation of human rights in the domestic legal system. To fulfil international cooperation the successor states had to incorporate laws in their constitutions by protecting the rights and freedoms of each individual at the international level and guarantee all citizens the right to respect, tolerance and equality in society. Through the legislation the new born 
successor states took a role in introducing a human rights reality as an idea toward new social justice.

In many ways, there were fears about whether the communist idea of social justice (i.e. the elimination of the class struggle) is being replaced by another abstraction left for interpretation, such as the Declaration of Human Rights followed by its own legislation within International Law as the new route towards a better society. Considering experience concerning the constitutional regulation of freedom of religion, for example, from Tito's Yugoslavia, the pressing question is whether in this 'new' context legislation alone will be sufficient for achieving its goal? This question has been challenging the local communities for years and the urgency of finding a good enough answer to the question has never been greater, considering that the tensions between different groups of nationalists in Bosnia and Herzegovina are these days even stronger than they were during the 90s, and the far right wing movements are growing fast across the Yugoslav successor states.

After the beginning of democratization in the 1990s and the dissolution of the Yugoslav federation, all successor states immediately abandoned the socialist understanding of religion as an exclusively private matter (manifested in the privacy of homes and places of worship). The new nation states changed constitutions and passed laws that are largely in line with international standards, providing a general guarantee for both individual and collective aspects of freedom of religion and their public manifestations. In Bosnia and Hercegovina freedom of religion is guaranteed by the Constitution of the Bosnia and Hercegovina and Entity Constitutions ${ }^{31}$, the Law on Freedom of Religion and Legal Status of churches and religious communities, and the agreements concluded between the state and religious communities. The Constitution of Bosnia and Herzegovina in Article II, regulating human rights and freedoms, guarantees the right to 'freedom of thought, conscience and religion'. Moreover, the same Article stipulates that the rights and freedoms contained in the European Convention on Human Rights and its Protocols directly apply and will have priority over all other domestic laws. ${ }^{32}$ In that sense we can say that the state through legislation attempts to reintroduce, normatively, rights and freedoms through the idea of human rights. In this clear implementation of the standards of the European Convention in local legislation the frequent use of the term 'public' regarding the place for expression of religion is evident. The Law on Religious Freedom enables the autonomy of the churches and religious communities. At the same time the state authorities are prohibited from interfering in their work and organization. The legislative stress on the term 'public' includes practicing of religion in open public places again, (as opposed to in the Former Yugoslav legislation) and by doing so it attempts to solve the contradiction between state controlled religious practice and the free practice of that right.

Another example of this position is the Law on Freedom of Religion and Legal Status of Religious Communities from 2004, ${ }^{33}$ which established a balance in terms of standardization of individual religious rights and freedoms and collective rights of churches and religious communities. But is this enough to change the local conditions in favour of respecting the whole list of HR prescribed by the International Declaration?

The problem is that although we have an institutional and functional separation of state and religious communities, in daily practice we can say that this model is applied in a different way than legislation would suggest. ${ }^{34}$ The society is still showing the lack of ability to embrace and incorporate the new principles in the local culture. Right-based approaches and legally binding claims, in this case have to a high degree led to the assumption that human 
rights are first and foremost owned by the state and secondly as an inbuilt safeguard for all individuals.

Providing religion with a new pivotal public role in the new nation states resulted in a much closer relationship between religion and politics than one thought possible after so many years of secular existence. Many years of marginalization and privatization of religion across the communist secular states resulted in an environment of reaffirmation of religion's presence in the public sphere as well as in politics. On a global level there has been a recent return to religion, which is the result amongst other things of the fall of the Eastern Bloc communism, the occurrence of new religious movements, and the appearance of fundamentalist tendencies which lead to new challenges in nation states. After a tragic conflict and consequently 20 years of being exposed to neo-liberalism, 'tradition defended in the traditional way' as the opposite of 'cosmopolitan tolerance' is an undesirable attempt to build up an identity that is being drastically challenged and unravelled by the process of globalization, posttraditionalization, and reflexivity. ${ }^{35}$

As the role of religion became more influential, religion and politics became not only related to but also interdependent on each other. The vulnerability of such interdependence is often protected by the demand for respect for their right to freedom of religion. This is why the Bosnia and Herzegovina state has difficulty in obtaining universal inclusion and preservation of normative legitimacy among those who refuse to follow the very same framework. ${ }^{36}$ Religious nationalism ${ }^{37}$ intervenes frequently in politics in the attempt to identify itself with the state authority by cleansing the state of all minorities, either by forcing them into exile or assimilating them under its own institution. Religion is used as means of exclusion of other religions as well as all those groups, who are not religious, for the purpose of a total identification of religious affiliation with ethnicity/nationhood which mobilises people for the transition from "the dream" of new national states into their moral and political legitimation, despite all the internal economic and political issues which followed the war. At the same time, the basic principles of common human values, regardless of their ethnic, religious or other affiliation as defined in Gregg's HR State normative minimalism 'for all' members of political community, ${ }^{38}$ represent nothing but danger for the dominant groups' survival as a homogenous entity. The ethnic diversity within a single religious group (Croatian Catholics or Serbian Orthodox) per today is only seen as something that needs to be suppressed and ignored. The role of religion in this context is in providing a basis for a group as well as an individual identity, which unfortunately is based on the nationalists' instrumentalization of religion as a factual ontologization of the existing social, political and cultural differences. ${ }^{39}$ Such policy leads towards a violation of individual rights and consequently return the original conflict. The emergence of intolerance and hate rooted in conflicts has to be countered by lifting into transparency this corrupt approach of misleading the masses into further segregation.

\section{Gregg's Human Rights State as a model for a sustainable solution for Bosnia}

\section{A Human Rights State - a start for a common ethos}

Here we argue that adopting Gregg's HRS concept in today's Bosnia and Herzegovina would be a way toward the development of a common ethos to safeguard the individual's autonomy from the culture, politics, and institutions that are currently compromising her human rights. The safeguard would be the result of developing a local political culture instead of a forced abstract international legislation that many of the local population already are sceptic towards. 
An acting autonomous political community would safeguard individual rights as an act of the self-determination of the communities. ${ }^{40}$ The community would then be able to understand why it is in its interest to protect all of its citizens instead of protecting only parts of its homogenized group, i.e. a community which would understand its interest in recognizing each individual as a subject of rights, especially the members of marginalized and under privileged groups. By choosing this strategy, adopting human rights locally generated and locally enforced human rights can regain their legitimacy in Bosnia and Herzegovina if everyone is respected as an individual, and only secondarily collectively. ${ }^{41}$ The idea of HRS secures the individual the most basic level of 'equilibrium' for ensuring the imperative of autonomy. A form of normative minimalism which would help getting back the legitimacy of the concept of human rights in post war-torn and still healing community that Bosnia and Herzegovina still is. ${ }^{42}$

Gregg's concept of HRS offers a possible plausible solution to the current state of affairs in $\mathrm{BiH}$ since it provides an account of human rights, which draws validity within a culture, an idea, belief, or practice in ways that members recognize and identify with. For Gregg local political culture, if charged with protecting the human rights it embraces, is more likely to make a serious effort to protect them than any coming from the outside would. ${ }^{43}$ Gregg's bottom-up approach in practice is continuous since it embraces universally valid human rights as rights of local provenance that one day may be universally embraced if all communities at some point freely came to embrace them. ${ }^{44}$ Since human rights are derived from a particular community they are also always contingent and particular and cannot without social and political context in which they are recognized and enforced. ${ }^{45}$

Cultural and religious diversity as a common identity that characterize Bosnian society or rather, Bosnian cosmopolitanism, ${ }^{46}$ which to a high degree reflects Gregg's idea of logic behind local political community, ${ }^{47}$ is increasingly seen by the nationalists, within the country's borders, as a suspect, unpatriotic attitude. One might say that the nationalists would probably favour the Universal declaration's vision of human rights over the Gregg's vision. This is exactly because of UDHR's delineation of rights, some of which are particular only to some cultures and some of which are particular to nation states, which embrace the prepolitical solidarity generators of ethnicity, blood, language, religion or beliefs about a shared fate. $^{48}$

This is exactly why adopting Gregg's idea of a Human Rights State would help to break down the use of religious labels as a shorthand for a wide variety of cultural and ethno-national differences. It would help taking a starting point in granting 'all basic rights from the short list to all individuals' so that these rights would no longer be a luxury only for the chosen few, those who belong to one of the three main congregations. It would help stopping religion from being a form of motivation, giving a sense of belonging as an extension of nationalist power. ${ }^{49}$ Finally, it would stop political strategies of religious and national institutions which practice conscious manipulation of individuals by means of religious and cultural symbolism for political gain of retaining the religious nationalism already established in the same manner through war. ${ }^{50}$ Currently, it is interesting to observe how religiosity and politicization of religion have become a trend in which the choice of the individual / citizen has a reversal logic from the one in Former Yugoslavia: choosing 'non religiosity' of all sorts is seen as 'choosing disloyalty to one's own group'.

In Bosnia and Herzegovina today, the social control by the nationalists and religious institutions is practiced by blocking off the basic right to autonomy of the individual. ${ }^{51}$ People 
are forced to choose an unambiguous 'rediscovered' homogenous group identity. The individual's "need" to belong to a group is exploited politically. Religious institutions became guardians of the state,${ }^{52}$ providing it with a religious political legitimacy. Religion maintains the direct connection to a source of social cohesion and takes over the role of the state as one of a marker of identity for all of its citizens (nation state). Through religious sacralisation of national identity a persuasive interpretation of a complex reality is provided. Such religious based group identities often play a critical role in maintaining intergroup conflict. The appeal to ethnic loyalty and nationalism, and moral legitimacy provide religion with a significant role in society. Religion gains control over another identity marker, which should remain neutral for all its citizens, a task that is actually intended for the state. Instead of introducing an inclusive secular approach (maximum inclusion and accommodation of religious observance) the HR state for example proposed by Gregg Benjamin ${ }^{53}$, where legislation is the starting point for legitimation for the secular state, the Bosnia and Herzegovina society controlled by religious institutions. These act as political agents, currently showing the opposite approach by introducing exclusion and discrimination based on religious affiliation and identity. Religion in Bosnia and Hercegovina, as in other Yugoslav successor states, has taken the role as a leader of the nation on the road to national purification which leads to a totalitarian state of mind in the sense that many Bosnia and Herzegovina citizens have been excluded from the community because of their lack of 'national purity' which in essence means 'religious purity'. The state of Bosnia and Herzegovina today recognizes only the rights of its citizens who are members of one or the three main congregation, since the state has been divided in 1995 by Dayton agreement along the ethnic (synonymized with religion) lines within its own population. Gregg's focus on 'normative minimalism' ${ }^{54}$ would be an answer to cultural relativism, which develops the list of human rights only from the perspective of western Christian countries as their primary source. ${ }^{55}$ Gregg takes a step further than Rawls ${ }^{56}$ and removes also religion amongst other rights from his short list of basic rights. In this way religion could not have a priority before everyone's right to food and shelter. Thus adopting a form of Gregg's 'normative minimalism' would help to break down the most intrusive example of the role of religion in building of a national identity in Bosnia and Hercegovina: religious identification's specific not only religious but also political and social content and assumptions.

\section{Gregg's autonomy - Stopping history from repeating itself?}

The reason why Gregg's threefold concept of autonomy ${ }^{57}$ could lead to a viable solution in a place such as Bosnia and Herzegovina is that it would allow the individual to choose her own way of existence free from all the pressures which are currently subjecting almost complete community to control. At the same, the time community would also be able to understand why it is in its own interest to protect its multi ethnic complex structures and instead keep the homogenous tendencies that every large religious community carries within its dogma, at bay.

Where in the Bosnia and Herzegovina context the need for adopting Gregg's threefold concept of autonomy is most clearly expressed is the question of the individual's choice of own identity and nationhood. This question has not only taken a huge role in defining political rhetoric, and ideology, but has gained influence on daily practice by inserting boundaries between its own citizens regarding 'imaginary' relation to their 'religious affiliation'. ${ }^{8}$

Instead of guarding the possibility of choosing the common ground for values drawn from the local political community as the Bosnia and Herzegovina state is, the territory is increasingly becoming a sum of hostile ethno-religious-nationalist political battles. Newly gained religious 
awareness took over the idea of what tolerance and accommodation mean, suggesting that these concepts may be inappropriate for a country that has a history of diversity, multiculturalism. ${ }^{59}$ In addition, interactions between the weak Bosnia and Herzegovina state and the so called constituent peoples have created a dynamic transnational social field for a reconstruction of the Bosnia and Herzegovina past and present, which in turn poses new questions of boundary-making within the Bosnia and Herzegovina nation as a whole. The belief in a narrative where religious affiliation is synonymized with ethnicity leads to the belief that religion is the same as ethnic or national identity. Political constructs maintain the new reality where religious affiliation has become a source of ethnicity. ${ }^{60}$ This approach is mostly used in the newly-established theory that the indigenous Bosnian people oversimplify the real state of affairs with the presumption that all Catholics in Bosnia are Croats, that all Orthodox are Serbs and that all Muslims are the only Bosniaks. Such conceptual constructions of identity give support to the process of destruction of the Bosnia and Herzegovina state by dividing its territory amongst its neighbouring countries, leaving central Bosnia and Herzegovina as the "Muslim" Bosnian mini-state. The fundamental role of religion in this context is to block the individual's autonomy (Gregg's concept) by above all, reducing the individual at every opportunity to group identity. Religion motivates, provides a sense of belonging and plays the role of an extension of the national authorities. Instead of being the result of individual autonomous choice, ethnic and national identities are formed as an ad hoc addition to political strategy and the conscious manipulation of cultural and religious symbols as remedy in achieving of political goals.

Following Gregg's theory and adopting as far as possible his model of autonomy in political practice would protect the individual from being taken advantage of by political and religious institutions. It would neutralize the effects of the dialectic between political and religious institutional power over the individual by not providing legitimacy to both political and religious interests and goals. It would reduce the interdependence of religion and politics which creates a space of exclusivity, and it would increase the menu of choices for the individual.

This possible solution for the challenges society is facing would first of all 'de-politicize' religion and 'return' religious institutions to their role of spiritual leadership for those citizens who wish for it. Religious institutions would not be able to take on the role of promoters of political ideology and represent the interests of certain groups of citizens as an interest of the whole population. It would no longer be possible to exploit individual psychological need to belong or the fear of exclusion from the group or community, which currently compels many individuals to unwillingly become part of the group and the community. The individual's right to identity ${ }^{61}$ (despite the complexity of personal identity, it is preserved and encouraged through privacy, personality rights and the right to self-expression) would no longer be reduced to the right of the group.

Unfortunately, it is clearly evident from the latest studies that today, the individual yet again is indirectly, as in former Yugoslavia, forced to 'choose', to declare and function as part of a group rather than as an individual. In the event that the individual does not want to be part of a group, the same group sanctioned their choice through the characterization as 'eligible' or 'ineligible'. This later has consequences for a number of situations necessary for a conducting a normal daily life.

The issue of a common Bosnia and Herzegovina identity as a nation, for all citizens of Bosnia and Herzegovina and their civil rights is minimized and denied by the neighbouring countries (Croatia and Serbia), which consequently may lead to the collapsing of the state itself. This long term strategy by religious political institutions has led to the fact that today we have a 
fragmented state with an 'ethnified' political and legal system. Communist party membership is in many ways replaced by congregation membership and the new system of inclusion and exclusion gains a new height.

\section{HR Education in the cognitive model as the starting point?}

The reason why Gregg's model of human rights education is relevant for situation in Bosnia and Herzegovina today is probably one of the saddest admissions of the effects that the 90s wars had: Bosnia and Herzegovina with a centuries long multi-ethnic tradition has been ethnically homogenized to the point where the country is divided into a Bosnia and Herzegovina federation (mainly by Muslims and Catholics) and the Republika Srpska (entity populated mainly by Orthodox population). Consequently educational institutions have been homogenized so that young generations of systematically segregated youth do not even during their school year has much contact with members of other ethnic groups. Ever since the 90s wars were over, the nationalist elites in control of educational policies have taken over the systematic institutional segregation of the students. ${ }^{62}$ From the human rights perspective, one of the most tragic results of the wars in 90s is undoubtable the fact that younger generations, unlike older generations, do not even have memories of how it was possible to live together with all other ethnic groups and without animosity.

Therefore the necessity of following Gregg's model of approaching human rights education as training of consciousness as a cognitive style ${ }^{63}$, a persuasion, that can be taught in schools, seems a necessity in the Bosnia and Herzegovina context even though his model is primarily meant as one at College level. In the case of Bosnia and Herzegovina it would be applicable because this model reaches across the most varied social, economic, and cultural conditions, and recognizes the individual as someone worthy of human rights. ${ }^{64}$ Human rights education focuses on an individual regardless of one's political community membership. It pursues values regardless of - even against- national boundaries, identities, and commitments. ${ }^{65}$

Should clients of the human rights education be only youth at universities? As Gregg stresses, human rights education on another level surpasses its institutional framework because it can be conducted on a citizen to citizen bases in everyday life which was made possible by gaining greater freedom from state control. Exchanging ideas which encourage thinking independent of centralized state legacy of standardized educational methods can help removing the communist legacy, such as lack of trust and the discouragement of individual personhood. ${ }^{66}$ An interesting fact is that these days communist legacy has been re-exploited for the control of individuals by the opportunism of religious fundamentalists who followed after that regime. ${ }^{67}$ One of the frameworks which Gregg stresses is education through NGOs for example which would in cooperation with local communities target problematic issues which need to be discussed in order to gain consciousness around importance of respecting human rights of the most vulnerable in the communities independent of their religious or ethnic affiliation. NGOs would help understanding that Human rights are cosmopolitan. Human rights, while they aspire to a global embrace and universal validity they still have the greatest purchase on the local level. In order to function in a certain context they have to resonate locally in the distinctiveness of its habitus. For any NGO in order to be able to bring to educate individuals into change they need to understand why the local population sees the world the way that it does. ${ }^{68}$

In Bosnia and Herzegovina today, the human rights cognitive style which already is oriented to both local circumstances and cosmopolitan goals would only in a way lead the young 
blissfully ignorant generations back to their centuries long tradition of multi-ethnicity. As human rights' cognitive style pursues cosmopolitanism it adapts cosmopolitan aspirations to particular contexts and venues. The richness of the Bosnia and Herzegovina culture as a civilizational crossing between the three global religions represents just that. It would focus on transforming the corresponding nation state and, on bringing about human rights-friendly domestic policy that would aspire to an eventual global community in which individuals everywhere become human rights bearers ${ }^{69}$ as well as human rights defenders something that eventually is transformed into a form for human rights patriotism. (p. 157) Patriotism reflected in Human Right to the rule of Law. (p. 174) Developing consciousness locally means regarding the members of one's community as potential co-constructors since a human rights style is always embedded in particular cultural and historical traditions. The fact that we, as an older generation, have our memories makes us candidates for recalling the images of plurality once possible, as a background for building bridges in our common search for the common ethos. While for younger generations within the educational system learning the cognitive model would be essential it would be also our job those who still remember how it was to live together without animosity to practice person to person learning. In this way the common ethos would be built amongst different local communities, ordinary people, not elites, where the common ethos only can be built on the basis of Greg's theory of HRS.

\section{Concluding remarks}

As exemplified by our arguments laid out above, even though the constitutions of Yugoslav successor states as such resemble any Western constitution, due to a serious attempt to build its laws and regulations close to the HR Declaration, the practice of respecting HR more than often falls short of accomplishing this constitutional ambition. Not even the ideal of HR is really accepted by anyone and especially not by the local religious authorities within the Southeast. Currently a flamboyant example of how the successor states are misusing the idea of the HR Declaration pretending to accept the values (human dignity) behind it, confirms Gregg's argument as to how the current format of the Declaration more than accommodates the exclusionary politics of the newly born nation states in the South-East. ${ }^{70}$ The selective choice of rights which were to be respected in the new successor states is determined by religious institutions, which act as political agents on various levels. The grass root scepticism is currently riding high since unfortunately, state authorities are terrified of acting since everyone and anyone these days demands the rights to be respected, while religious institutions acting as political agents increase their political power through applying democratic methods to achieve totalitarian goals. The state apparatus as it functions today has lost its opportunity to offer an alternative perspective and by protecting group rights, the state forgot to grant the right to individuals to choose their own way. Religion has become a group exercise holding the individual perspective as a hostage. The state has lost its capability to guarantee fundamental civil rights to all citizens, that is, the right to choose as well as the right to be protected from having to choose.

We argue therefore that the Bosnia and Herzegovina peoples' search for sustainable peace and prosperity lies within the framework of Gregg's theory of the Human Rights State. If Gregg's perspective would be promoted in today's Bosnia and Herzegovina it would have been a question of developing a culture as well as enhancing the development of cultural consciousness for dealing with the multiple ethnic minorities that at all times actually outnumber religious congregations in the area. Having a common ethos on the state level would help overcome the local history of ethno religious nationalist conflicts based on the politicization of religion through synonymization of religious affiliation with ethnicity. 


\section{Disclosure statement}

There is no potential conflict of interest to report.

\section{Notes on contributors}

Gorana Ognjenović is currently Research Fellow at the University in Oslo, Norway. Previously she was Fulbright Scholar at New School for Social Research. She is contributing editor of an anthology Responsibility in Context (Springer 2009) and contributing co-editor with Jasna Jozelić of: Education in Post-Conflict Transition, The Politicization of Religion in School Textbooks, Palgrave Studies in Religion, Politics and Policy, (2017); Revolutionary Totalitarianism, Pragmatic Socialism, Transition (Palgrave 2016), Titoism, Selfdetermination, Nationalism, Cultural Memory (Palgrave 2016), Politicization of Religion, The Power of Symbolism, Palgrave Studies in Religion, Politics and Policy (2014) and Politicization of Religion, The Power of State, Nation, Faith, Palgrave Studies in Religion, Politics and Policy (2014).

Jasna Jozelić is Advisor and Dr. philos candidate at the University in Oslo, Norway. She is contributing co-editor with Gorana Ognjenović of: Education in Post-Conflict Transition, The Politicization of Religion in School Textbooks, Palgrave Studies in Religion, Politics and Policy, (2017); Revolutionary Totalitarianism, Pragmatic Socialism, Transition (Palgrave 2016), Titoism, Self-determination, Nationalism, Cultural Memory (Palgrave 2016), Politicization of Religion, The Power of Symbolism, Palgrave Studies in Religion, Politics and Policy (2014) and Politicization of Religion, The Power of State, Nation, Faith, Palgrave Studies in Religion, Politics and Policy (2014).

\footnotetext{
${ }^{1}$ Anthony Giddens, Beyond Left and Right: The Future of Radical Politics (Cambridge; Polity, 1994): 242.

${ }^{2}$ Keith Tester, Foreword in Politicization of Religion, The power of Symbolism: The case of Former Yugoslavia and its Successor States, eds. Gorana Ognjenović \& Jasna Jozelić, Palgrave Studies in Religion, Politics and Policy, (Palgrave, 2014): xiv.

${ }^{3}$ Judith Nagata, (Jun 2001). 'Beyond Theology: Toward an Anthropology of "Fundamentalism'. American Anthropologist. 103 (2): 481-498.

${ }^{4}$ Gorana Ognjenović \& Jasna Jozelić (eds), Politicization of Religion, The power of State, Nation, and Faith: The case of Former Yugoslavia and its Successor States, Palgrave Studies in Religion, Politics and Policy, (Palgrave: 2014).

${ }^{5}$ Religious nationalism here understood as the relationship between nationalism and a particular religious belief, dogma, or affiliation, where religion influences politics ideologically. Interpretations of religious ideas which motivate political action, such as when laws are passed to foster stricter religious adherence. See Mark Juergensmeyer 'The Worldwide Rise of Religious Nationalism', Journal of International Affairs, (Summer 1996) $50,1$.

${ }^{6}$ Fundamentalism here understood as: unwavering attachment to a set of irreducible beliefs. Judith Nagata, 'Beyond Theology: Toward an Anthropology of "Fundamentalism', American Anthropologist. 103 (2) (Jun 2001): 481-498.

${ }^{7}$ Ivan Iveković, 'Nationalism and the Political Use and Abuse of Religion: The Politicization of Orthodoxy, Catholicism and Islam in Yugoslav Successor States', Social compass 49(4), (2002, Sage): 523.

${ }^{8}$ Nena Mocnik, 'Religious Symbolism and Mythology in Sexual Violence and Rape during the Balkan Conflict, 1992-1995' in Politicization of Religion, The power of Symbolism: The case of Former Yugoslavia and its
} 
Successor States, eds. Gorana Ognjenović \& Jasna Jozelić, Palgrave Studies in Religion, Politics and Policy (Palgrave, 2014).

${ }^{9}$ Marjan Smrke, 'Ethno-religious mimicry in the war in Bosnia-Herzegovina', in Politicization of Religion, The power of Symbolism: The case of Former Yugoslavia and its Successor States, eds. Gorana Ognjenović \& Jasna Jozelić, Palgrave Studies in Religion, Politics and Policy, (Palgrave, 2014).

${ }^{10}$ Latinka Perović, 'Dobrica Ćosić and Josip Broz Tito-A Political and Intellectual Relationship', in Titoism, Self-Determination, Nationalism, Cultural Memory, Volume Two, Tito's Yugoslavia, Stories Untold, eds. Gorana Ognjenović \& Jasna Jozelić, (Palgrave, 2016).

${ }^{11}$ Frano Prcela, 'The Catholic Pledge in the Croatian Identity' in Politicization of Religion, The power of Symbolism: The case of Former Yugoslavia and its Successor States, eds. Gorana Ognjenović \& Jasna Jozelić, Palgrave Studies in Religion, Politics and Policy (Palgrave 2014).

${ }^{12}$ Respecting the right to freedom of religion is an expression of acceptance of building constitutions based on the premises set by Human Rights Declaration.

${ }^{13}$ Srdjan Vrcan, The War in ex-Yugoslavia and Religion, Social Compass 41(3), (Sage 1994): 413-422.

${ }^{14}$ Ivan Iveković, Nationalism and the Political Use and Abuse of Religion: The Politicization of Orthodoxy, Catholicism and Islam in Yugoslav Successor States, Social compass 49(4), (Sage 2002): 534.

${ }^{15}$ Jasna Jozelić, 'Politicization of Religion: The Case of Bosnia-Herzegovina' in Politicization of Religion, The power of State, Nation, and Faith: The case of Former Yugoslavia and its Successor States, eds. Gorana Ognjenović \& Jasna Jozelić, Palgrave Studies in Religion, Politics and Policy (Palgrave 2014).

${ }^{16}$ Republika Srpska nowdays is attempting to organize referendum for establishing a nationalistic holiday which is against the constitution of the state of Bosnia and Herzegovina, a referendum which the High Court of Bosnia and Herzegovina does not recognize.

${ }^{17}$ This division along main ethnic lines ignored presence of other groups, Jews and Roma, whose representatives took the Bosnian state to European Human Rights court. Christopher McCrudden and Brendan O'Leary, Courts and Consociations, or How Human Rights Courts May De-stabilize Power-sharing Settlements, European Journal of International Law, Volume 24, Issue 2. (2013): 477-501.

${ }^{18}$ Gorana Ognjenović \& Jasna Jozelić (eds), Politicization of Religion, The power of Symbolism: The case of Former Yugoslavia and its Successor States, Palgrave Studies in Religion, Politics and Policy (Palgrave 2014) .

${ }^{19}$ Benjamin Gregg, Human Rights as Social Construction, (Cambridge University Press 2012): 230.

${ }^{20}$ Benjamin Gregg, Human Rights as Social Construction, (Cambridge University Press 2012): 231.

${ }^{21}$ Stanford encyclopedia of Philosophy, Human Rights, (Retrived August 14, 2016)

${ }^{22}$ Benjamin Gregg, Human Rights as Social Construction, (Cambridge University Press 2012): 213

${ }^{23}$ Ustav Federativne Narodne Republike Jugoslavije (1946), Glava V, Prava i dužnosti gradjana, član 25.

${ }^{24}$ Slobodan Nesović and Branko Petranović, AVNOJ i revolucija (Beograd: Nolit, 1983): 696.

${ }^{25}$ Sabrina Petra Ramet (ed) Religious Policy in the Soviet Union (Cambridge University Press.1993): 4; John Anderson, Religion, State and Politics in the Soviet Union and Successor States. (Cambridge, England: Cambridge University Press 1994): 3.

${ }^{26}$ Benjamin Gregg, Human Rights as Social Construction, (Cambridge University Press 2012): 215.

${ }^{27}$ By 1971 there were 1000000 people who voluntary declared themselves as Yugoslavs.

${ }^{28}$ Gorana Ognjenović, Nataša Mataušić, Jasna Jozelić, 'Yugoslavia's Authentic Socialism as a Pursuit of 'Absolute Modernity' in Titoism, Self-Determination, Nationalism, Cultural Memory, Volume Two, Tito's Yugoslavia, Stories Untold, eds. Gorana Ognjenović \& Jasna Jozelić (Palgrave 2016)

${ }^{29}$ Tvrtko Jakovina, 'It's Either Tito or the Soviet Aparatchik' in Revolutionary Totalitarianism, Pragmatic Socialism, Transition, Volume One, Tito's Yugoslavia, Stories Untold, eds Gorana Ognjenović \& Jasna Jozelić, (Palgrave 2016).

${ }^{30}$ On the territory of Former Yugoslavia and its successor states there are many different traditions within a single religious belief. The heavy intertwining of the two symbolisms was made during the 90 s for the purpose of assimilating different traditions under one dominated by either Croats Catholic Church (Crkva u Hrvata) or Serbian Orthodox Church in order to occupy the parts of territory of Bosnia and Herzegovina during the 90s until today. As well as early in the 90s occupying Croatian territories by Serbia by means of definition made by the Serbian Orthodox Church 'all Serbs in one state'. 
${ }^{31}$ The constitution determined by the Dayton peace agreement and its systematic flaws. See Gro Nystuen, Achieving peace or protecting human rights?: conflicts between norms regarding ethnic discrimination in the Dayton Peace Agreement Raoul Wallenberg Institute human rights library vol. 23 (2005)

${ }^{32}$ Ustav Federacije Bosne i Hercegovine, Službene Novine Federacije Bosne i Hercegovine, 1/94, 13/97, $16 / 02$.

${ }^{33}$ Zakon o slobodi vjere i pravnom položaju crkava i vjerskih zajednica u Bosni i Hercegovini, Službeni glasnik Bosne i Hercegovine, 5/04

${ }^{34}$ Human Rights Papers, Paper 23; BiH Alternative rapport 2016, Political Criteria, Sarajevo, (July 2016), ISSN 2303-6079

${ }^{35}$ Gorana Ognjenović \& Jasna Jozelić, Politicization of religion, The Power of State, Nation, and Faith: The Case of Former Yugoslavia and its Successor States, Palgrave Studies in Religion, Politics and Policy, (Palgrave 2014).

${ }^{36}$ Bureau of Democracy, Human Rights, and Labor, 2014 Report on International Religious Freedom, BOSNIA AND HERZEGOVINA (October 14, 2015) http://www.state.gov/documents/organization/238574.pdf

${ }^{37}$ Gorana Ognjenović \& Jasna Jozelić eds., Politicization of Religion, The power of Symbolism: The case of Former Yugoslavia and its Successor States, Palgrave Studies in Religion, Politics and Policy, (Palgrave 2014); Gorana Ognjenović \& Jasna Jozelić eds., Politicization of religion, The power of State, Nation, and Faith: The Case of Former Yugoslavia and its Successor States, Palgrave Studies in Religion, Politics and Policy, (Palgrave 2014); Sabrina Petra Ramet, Religion and Politics in Post-Socialist Central and Southeastern Europe, Challenges since 1989, Palgrave Studies in Religion, Politics and Policy (Palgrave 2014); Branislav Radeljić \& Martina Topić, Religion in the Post-Yugoslav Context, (Lexington Books, 2015).

${ }^{38}$ Benjamin Gregg, Human Rights as Social Construction, (Cambridge University Press 2012): 229.

${ }^{39}$ Srdjan Vrcan, The War in ex-Yugoslavia and Religion, Social Compass 41(3), (Sage 1994): 418.

${ }^{40}$ Benjamin Gregg, Human Rights as Social Construction, (Cambridge University Press 2012): 228.

${ }^{41}$ Ibid., 229.

42 The protection of his or her physical well-being (the right not to be killed, not to be subjected to gratuitous pain, or the right to the satisfaction of basic needs with respect to food, shelter, or basic medical care). And it would secure the protection of his or her psychological well-being (personal liberties of speech, association, and conscience). Ibid. 229-230.

${ }^{43}$ Ibid., 213.

${ }^{44}$ Ibid. , 214.

45 Ibid., 215-216.

${ }^{46}$ Centuries of co-existence of various religious communities and ethnic groups which together have a common Bosnian national identity.

${ }^{47}$ Benjamin Gregg, Human Rights as Social Construction, (Cambridge University Press 2012): 230.

${ }^{48}$ Ibid., 217-218.

${ }^{49}$ Jasna Jozelić, 'Politicization of Religion: The Case of Bosnia-Herzegovina' in Politicization of Religion, The power of State, Nation, and Faith: The case of Former Yugoslavia and its Successor States, eds. Gorana Ognjenović \& Jasna Jozelić, Palgrave Studies in Religion, Politics and Policy, (Palgrave 2014).

${ }^{50}$ Marjan Smrke, 'Ethno-religious mimicry in the war in Bosnia-Herzegovina', in Politicization of Religion, The power of Symbolism: The case of Former Yugoslavia and its Successor States, eds. Gorana Ognjenović \& Jasna Jozelić, Palgrave Studies in Religion, Politics and Policy, (Palgrave 2014).

${ }^{51}$ Drago Bojić, 'Zlato i tamjan: kritički osvrti na politiku i religiju', CKM (Centar za kritičko mišljenje), (Mostar, 2016).

${ }^{52}$ Frano Prcela, 'The Catholic Pledge in the Croatian Identity', in Politicization of Religion, The power of Symbolism: The case of Former Yugoslavia and its Successor States, eds. Gorana Ognjenović \& Jasna Jozelić Palgrave Studies in Religion, Politics and Policy, (Palgrave 2014).

${ }^{53}$ By taking religion off the list of basic rights.

${ }^{54}$ Benjamin Gregg, Human Rights as Social Construction, (Cambridge University Press 2012): 230.

${ }^{55}$ This particular aspect is of great importance and sensitivity in this context as the war resulted in genocidal practices against the Bosnian Muslim population.

${ }^{56}$ John Rawls, The Law of Peoples, (Cambridge: Harvard University Press 1999): 65.

${ }^{57}$ Benjamin Gregg, Human Rights as Social Construction, (Cambridge University Press 2012): 231.

${ }^{58}$ There is an ongoing political battle between Bosnia and Herzegovina, Croatia and Serbia where the last two are refusing to acknowledge Bosnia's state borders by referring to Bosnian Catholics as Croats and Bosnian 
Orthodox as Serbians. There are of course a number of Croats and Serbians who are citizens of Bosnia and Herzegovina but they remain a tiny minority that could never be able to claim their own state within a state (that would eventually unite with their imaginary reserve homelands Croatia and Serbia) based on being the majority of the population in certain parts of the territory of Bosnia and Herzegovina.

${ }^{59}$ What makes Bosnia and Herzegovina special regarding the multiculturalism today is that this multiculturalism for centuries has been an expression of tolerance between the Christian and Islamic tradition of a special kind since Bosnian Muslims are Christians who converted to Islam during the Ottoman invasion of Europe.

${ }^{60}$ Jasna Jozelić, 'Politicization of Religion: The Case of Bosnia-Herzegovina', in Politicization of Religion, The power of State, Nation, and Faith: The case of Former Yugoslavia and its Successor States, eds. Gorana Ognjenović \& Jasna Jozelić, Palgrave Studies in Religion, Politics and Policy, (Palgrave 2014).

${ }^{61}$ Jill Marshall, 'The legal recognition of personality: full-face veils and permissible choice', International Journal of Law in Context, (Cambridge University Press, 2014): 72.

${ }^{62}$ Gorana Ognjenović \& Jasna Jozelić, Education in Post-Conflict Transition, The Politicization of Religion in School Textbooks, Palgrave Studies in Religion, Politics and Policy, (Palgrave 2017).

${ }^{63}$ Benjamin Gregg, The Human Rights State, Pennsylvania Studies in Human Rights, (University of Pennsylvania Press, Philadelphia, 2016): 84.

${ }^{64}$ Ibid., 86.

${ }^{65}$ Ibid., 113.

${ }^{66}$ Ibid., 112.

${ }^{67}$ Clemens Cavallin \& Sead Fetahagić, 'The Role of the Catholic Church in the Bosnian Conflict 1992-1995: A Historical Approach', in Politicization of Religion, The power of State, Nation, and Faith: The case of Former Yugoslavia and its Successor States, eds. Gorana Ognjenović \& Jasna Jozelić, Palgrave Studies in Religion, Politics and Policy, (Palgrave 2014).

${ }^{68}$ Benjamin Gregg, The Human Rights State, Pennsylvania Studies in Human Rights, (University of Pennsylvania Press, Philadelphia, 2016): 109.

${ }^{69}$ Ibid., 115.

${ }^{70}$ Benjamin Gregg, Human Rights as Social Construction, (Cambridge University Press 2012): 226. 